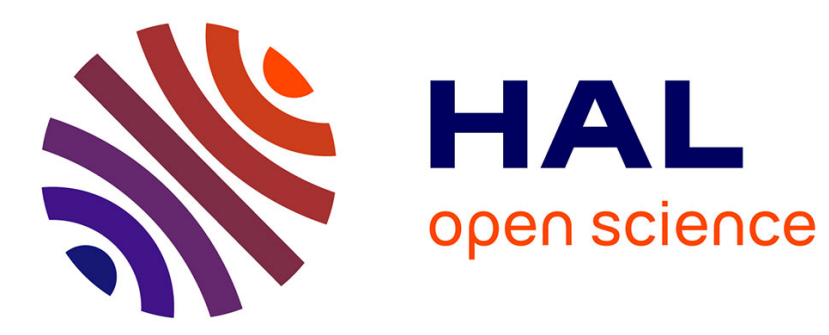

\title{
Exploring the role of objects in the transformation of logics: a practice perspective
}

\author{
Diane-Laure Arjaliès
}

\section{To cite this version:}

Diane-Laure Arjaliès. Exploring the role of objects in the transformation of logics: a practice perspective. 2011. hal-00633462

\section{HAL Id: hal-00633462 https://hal-hec.archives-ouvertes.fr/hal-00633462}

Submitted on 18 Oct 2011

HAL is a multi-disciplinary open access archive for the deposit and dissemination of scientific research documents, whether they are published or not. The documents may come from teaching and research institutions in France or abroad, or from public or private research centers.
L'archive ouverte pluridisciplinaire HAL, est destinée au dépôt et à la diffusion de documents scientifiques de niveau recherche, publiés ou non, émanant des établissements d'enseignement et de recherche français ou étrangers, des laboratoires publics ou privés. 
Exploring the Role of Objects in the

Transformation of Logics: A Practice Perspective

Diane-Laure ARJALIES

HEC School of Management, Paris, France

CR 952-2011

ISBN : 2-85418-952-3

(C) Groupe HEC, 78351 JOUY-EN-JOSAS CEDEX, France, 2011

ISBN : 2-85418-952-3 


\title{
Exploring the Role of Objects in the Transformation of Logics: A Practice Perspective
}

\author{
Diane-Laure Arjaliès ${ }^{1}$ \\ Accounting and Control Department \\ HEC Paris \\ 1 rue de la Libération \\ 78351 - Jouy-en-Josas \\ France \\ arjalies@hec.fr
}

\begin{abstract}
$\underline{\text { Abstract }}$
This article aims to examine the role of objects in the transformation of logics (Thornton \& Ocasio, 2008) at the practice level. In particular, it explores how financial actors use, transform and are constrained by their 'market devices' - defined as a range of instruments, models and tools used by financial markets (Callon, Millo, \& Muniesa, 2007) - when aiming to (re)design their logics and practices towards more sustainability. It develops a theoretical model based on ever expanding, institutional theory by combining it with practice theories. In particular, the article argues that actors transform their practices, logics and objects, by transforming an epistemic object through a collective inquiry. Empirical support is drawn from a threeyear ethnography study of a French asset management company that attempted to (re)design its equity investment process, following new demands for Socially Responsible Investment (SRI). Research methods combine participative observation, semi-structured interviews and documentary evidence. Theoretical and methodological contributions are outlined for both institutional and practice theories.
\end{abstract}

Key-words: Inquiry - Logics - Objects - Practices - Pragmatism

${ }^{1}$ The author wishes to thank Ravi Dar, Johan Gregeby, Philippe Lorino, Nicolas Mottis and participants of the Pragmatist Track of EGOS Conference in July 2008 and of the research seminars of Uppsala University (October 2008), ESSEC Business School (February 2009) and Paris Ouest Nanterre La Défense University (April 2009) for their constructive comments and criticisms. 
AUTHOR: Now that the (re)design is finished, do you think that the (re)organizing should have been done in a different way?

PROJECT MANAGER: Of course! We should have formalized the organizational revival to a much greater extent. Things were done any old how.

\section{Introduction}

Interest in institutional logics has grown rapidly over the past 15 years. At the level of industries, logics consist of 'identities and valuation orders that structure the decision making and the practices of the players in a product market' (Thornton \& Ocasio, 1999). Since they pre-condition choices for sense making, acting and identity (Thornton, Ocasio, \& Lounsbury, forthcoming), logics play a key role in the unfolding and the transformation of practices.

Over the past two decades, a number of scholars have stressed the need to pay more attention to the intra-organizational level of practices to understand how logics are transformed and new practices emerge in response to institutional change (Barley, 2008; Lounsbury \& Crumley, 2007; Powell \& Colyvas, 2008). In particular, whereas logics are reproduced through the everyday practices of actors, little research has been conducted that directly examines the transformation of logics within organizations. Furthermore, much of the work at the organizational level has tended to focus on heroic actors or successful social movements, but has seldom studied how actors behave and interpret their institutional context in concrete social situations (DiMaggio \& Powell, 1991; Powell \& Colyvas, 2008; Zilber, 2002).

This article is an attempt to address this shortcoming. In an effort to explore how logics are transformed at the practice level, it particularly aims to study the role of objects in this transformation. Indeed, despite the fact that the idea of including objects in organization studies is not new (Carlile, 2002; Knorr-Cetina, 1997; Latour, 1987), we still know little about the role of objects in the process of organizing and transformation of logics (Kaghan \& Lounsbury, 2005; Miller, 2008; Spee \& Jarzbkowski, 2009). In particular, further research is needed about the mediating role of objects in the transformation of practices by actors: 'it alerts us to the ways in which certain instruments or models can "mediate" between actors and arenas such as science and the economy' (Miller \& O'Leary, 2007). These arguments have been extended with respect to financial markets and financial knowledge. While it is now well recognized that financial models shape markets (MacKenzie, 2006), how and why these market devices frame the logics and practices of financial actors remains relatively unknown (Callon et al., 2007).

To remedy these problems, this article follows several calls for bridging practice with institutional theories (Lounsbury \& Crumley, 2007; Smets, Morris, \& Greenwood, 2011; Thornton et al., forthcoming; Weick, Sutcliffe, \& Obstfeld, 2005). To bring these perspectives together, the article combines the concept of logics (Thornton \& Ocasio, 2008) with the concept of technical and epistemic object (Knorr-Cetina, 1995, 1997; Rheinberger, 1992, 1997). An epistemic object is any object under research: an 'object which embodies what one does not yet know' (Rheinberger, 1992). When an epistemic object is sufficiently stable, it becomes a technical object: an object which embodies the knowledge available at a given moment in time.

The article studies the different phases through which a working group inside an asset management company aimed to transform their logics and practices following new demands for Socially Responsible Investment (SRI). The article uses a three-year ethnography study (2006-2009) following a pragmatist epistemology (Dewey, 1938; Peirce, 1931), based on semi-structured interviews, participative observation and documentary evidence. The article analyzes how actors progressively transformed their logics and practices through transforming their market devices. 
The article argues that logics, practices and objects all structure and depend on each other. In particular, it shows that actors transform their logics and practices through transforming their objects. Former technical objects become epistemic objects (i.e. generate new knowledge) and provide actors with a medium to transform their logics and practices. To demonstrate so, the article reports on how an asset management company transformed it logics and practices following new demands for SRI. It shows that this transformation was obtained through the market devices they used, such as the representation of investment processes, financial models, indicators or performance measurement systems.

The contribution of the article is twofold: theoretical and methodological. Firstly, it expands institutional theories by linking institutional to practice theories. In doing so, it also enables the broadening of recent work on practice, which has tended to emphasize the localized meanings of practices over the institutional sources of meaning that participate in framing these practices (Jarzbkowski, 2004). Additionally, by focusing on the role of objects, the article offers new perspectives on how institutional logics are instantiated in and carried by actors through their instruments. Secondly, the article elaborates on the relevance and implications of pragmatist epistemology to explore institutional change in practice.

The article is structured as follows. Section 2 develops the theoretical framework. Section 3 introduces the case study features. Section 4 explains the research methods. Section 5 presents the case study findings. Lastly, section 6 discusses the findings and points to further research.

\section{Theoretical Background}

\subsection{Transforming Practices in Response to Institutional Change}

Institutions are the 'taken-for-granted assumptions which underpin the rules and routines that shape day-to-day practices' (Burns \& Scapens, 2000). Institutions provide guidance on how actors should behave in an organizational field. An organizational field was defined by DiMaggio and Powell (1983) as:

Those organizations that, in the aggregate, constitute a recognized area of institutional life: key suppliers, resource and product consumers, regulatory agencies and other organizations that produce similar services or products.

In this article, the organizational field under study is the French asset management sector. Institutions are perceived as taken-for-granted 'efficacious' and 'necessary' requirements to 'generate action' (Tolbert \& Zucker, 1996). As shared systems of meaning, institutions can be legal and/or cultural rules or beliefs (Scott, 2001). To perform institutions, actors rely on institutional logics (Friedland, 2009; Friedland \& Alford, 1991; Thornton \& Ocasio, 1999, 2008), which provide the schemes of meaning by which actors make sense of institutions in practice. Institutional logics can be defined as a 'set of material practices and symbolic constructions - which constitutes its organizing principles and which is available to organizations and individuals to elaborate' (Friedland \& Alford, 1991).

According to institutional theories, in the face of institutional change, organizations would be likely to decouple their formal structures from their practices in order to meet both institutional and technical demands (Brusson, 2002; Meyer \& Rowan, 1977; Scott, 2001). These institutional pressures would explain why organizations in an organizational field would tend to adopt the same form and why institutional change would have not been historically perceived as a trigger for practical change. However, over the past two decades, an increasing number of institutional scholars have nuanced this decoupling perspective. Notably, they have explored how new practices are implemented and internalized in response to institutional change, a process known as institutionalization (Hasselbladh \& Kallinikos, 2000; Kostova \& Roth, 2002; Sahlin \& Wedlin, 2008; Zucker, 1988). Firstly, they have demonstrated that decoupling is not the only answer to new institutional requirements (Abernethy \& 
Chua, 1996; Oliver, 1991). Secondly, they have argued that even if actors deliberately choose to decouple their symbolic displays from technical operations, the ceremonial implementation of the new institutions can have - intentionally or not - impacts on practices (Basu \& Dirsmith, 1999; Dambrin, Lambert, \& Sponem, 2007; Siti-Nahiba \& Scapens, 2005). Notably, they have argued that the transformation of practices in response to institutional change is a process contingent upon actors and context (Hopper \& Major, 2007; Lounsbury, 2008; Lounsbury \& Crumley, 2007). Namely, it depends on how actors collectively transform their institutional logics (Bogt \& Scapens, 2009; Lounsbury, 2001). Nevertheless, still largely missing is a better understanding of the micro-dynamics of practical change (Powell \& Colyvas, 2008; Zucker, 1991). Particularly, the juxtaposition of practice and institutional theories has been rare (Weick, 1995). To fill this gap, the next sections suggest a theoretical framework, based on practice and institutional theories, to understand how actors maintain or transform the institutional forces that guide daily practices.

\subsection{The Need for a Collective Inquiry}

Institutional change disrupts practices: actors are no longer able to maintain their usual activity. When several actors are committed to the same activity (i.e. when they depend on each other), they have to collectively investigate the situation to make sense in practice of the new institutions conveyed by institutional change. In other words, a collective inquiry begins. The concept of inquiry was first developed by pragmatist authors (Dewey, 1938; Peirce, 1931), who 'considered the development of knowledge as an adaptive human/social response to environment conditions and an active restructuring of the environment' (Lorino, Tricard, \& Clot, 2010). According to Dewey (1938), an inquiry is:

The controlled or directed transformation of an indeterminate situation into one that is so determinate in its constituent distinctions and relations as to convert the elements of the original situation into a unified whole.

A collective inquiry can be defined as the investigation processes - mobilized by a group of actors committed to the same collective activity - to make sense of an uncertain and disrupted situation. Collective activity refers to the processes through which actors cooperate to collectively accomplish the purpose of their group (Lorino, 2006). Since it depends on actors who participate in it, an inquiry is always physically and temporally situated; which explains why institutional, political, cognitive, emotional, ethical and contextual elements participate in its framing. Notably, a collective inquiry is characterized by the following features:

- The inquiry is triggered by an 'existential unease': usual practices no longer enable actors to overcome the obstacles of everyday life.

- The process of inquiry mobilizes an abductive mode of reasoning (Peirce, 1931), which consists of generating new hypotheses and stories that account for the situation in a plausible way. Abduction comprises intuition, reasoning, narrative thinking and experimentation.

- The inquiry is both mediated and mediating (Lorino et al., 2010). To investigate, actors carry, use and transform mediations, which can be speech, discourses, texts or figures. The inquiry embodies a problem in speech and instruments and transforms the speech and instruments as it transforms the embodied knowledge.

In particular, Dewey (1938) suggests the following pattern for the inquiry:

1. THE ANTECEDENT CONDITIONS OF INQUIRY: for an inquiry to begin, the indeterminate situation must be questionable. In other words, it must be uncertain, unsettled, disturbed. Neither actors nor the situation considered separately are doubtful; it is the relationship between actors and the situation which is doubtful: actors are no longer able to make sense of the situation.

2. INSTITUTION OF A PROBLEM: the initial step of an inquiry is to admit that the situation requires an inquiry since it is doubtful. The definition of the problem represents the partial transformation by the inquiry of an indeterminate situation into a determined one. Since 
properly formulating a problem constitutes a way of finding a solution, the determination of the problem itself is a progressive inquiry.

3. THE DETERMINATION OF A PROBLEM-SOLUTION: both hypothesis (ideas) and experimentation (verification by the facts) evolve through successive mutual iterations: a plausible story is then progressively built. For this purpose, several round trips between facts and ideas are necessary: 'the possible solution presents itself, therefore, as an idea, just as the terms of the problem (which are facts) are instituted by observation' (Dewey, 1938).

4. REASONING: hypotheses (plausible narratives) generated by the abduction process must lead to propositions which can be practically experimented, through logical inferences (deduction, induction).

5. THE OPERATIONAL CHARACTER OF FACTS-MEANINGS: practices cannot be (re)designed unless both facts and ideas are recognized as operational. For this purpose, ideas and facts must be experimented to be practically accepted and verified. The inquiry is successful when this goal is achieved. The suggested solution is twofold: new practices to overcome the practical difficulties of the situation which triggered the inquiry and new concepts which could be used in future inquiries are generated.

Despite being sequential in the sense that there is a 'trigger' at its beginning and a conclusion at its end, the inquiry is a continuous process of investigation. The abductive (building of hypotheses), deductive (the progress of causal logical relationships) and inductive stages (experiment protocols) intertwine through the inquiry.

\subsection{The Role of Objects}

Two types of objects play an important role in the inquiry: epistemic and technical objects (KnorrCetina, 1995, 1997; Rheinberger, 1992, 1997). An epistemic object is any object under research: an 'object which embodies what one does not yet know' (Rheinberger, 1992). A technical object is a stable object, which embodies the knowledge available at a given moment in time. Both types of objects are mediating instruments. Technical objects provide actors with resources which are engaged to transform their practices and receive a lateral attention from them, whereas epistemic objects appear as the focal object of their transforming efforts: actors transform their practices through them. For instance, financial models are often technical objects which are used as a daily, steady and unproblematic resource by actors. If the financial models 'fail', they generate questions and become epistemic objects. Epistemic objects can be transformed into technical objects and vice versa. Indeed, instruments 'are simultaneously things-to-be-used and things-in-a-process-of-transformation' (KnorrCetina, 1997). For instance, a management system which is used as a daily, steady and unproblematic resource by actors is a technical object. As soon as the management system 'breaks down', it generates questions and becomes an epistemic object. At that instant, actors are likely to investigate the situation to repair the management system and transform it back into a technical object. Hence, an object is epistemic or technical according to its status in the situation not because of its intrinsic nature. In other words, objects can be either technical or epistemic, depending on their role in actors' practices.

The practices associated with each type of object are not theoretically identical. A technical object is associated with 'usual' practices; which refer to what actors habitually do in their everyday life. This relates to how they perform their institutional logics and technical objects in their day-to-day practices. This comprises also what they do not do and what they would like to do: the different "potential practices' associated with this object. When the relationship between the technical object and its associated practices is disrupted, it becomes an epistemic object. At this moment, the usual practices no longer allow actors to maintain their collective activity. Triggered by this 'existential unease', an inquiry whose purpose is to (re)build usual practices in order to transform the epistemic object back to a technical object begins (cf. figure 2.1). Through the inquiry, new 'usual' practices are generated to be associated with the new version of the technical object (i.e. which assumes continuity between the two versions of the technical object). For this purpose, actors can mobilize all the 'potential' practices associated with their technical object (i.e. those that are not usually enacted but which could be 
enacted). The epistemic object is said to revert back to a technical object when its associated practices are recognized by inquiry participants as the (new) 'usual' ones. Hence, the practices associated with the epistemic object do not relate to actors' day-to-day practices but to the inquiry's practices. However, the identification of the disrupted technical object - the epistemic object which needs to be transformed - is not obvious. This identification depends on the ability of inquiry participants to define the problem they face (cf. section 2.2).

This distinction between technical and epistemic objects is very useful when exploring the transformation of logics in the financial sector. Indeed, the more a market devices - defined as a range of instruments, models and tools used by financial markets (Callon et al., 2007) - are considered as steady and reliable resources, the more they will be used and the less they will be questioned (MacKenzie \& Millo, 2003). Then, market devices are likely to be used as technical objects on which financial actors could rely. The object and its associated logics and practices then become 'institutionalized'. Reciprocally, since the market devices act as mediating objects between actors and the financial markets, their questioning inevitably questions its associated logics and practices. Thus, the transformation of logics and practices could not be obtained without the transformation of the latter. In such a case, market devices play the role of epistemic objects.

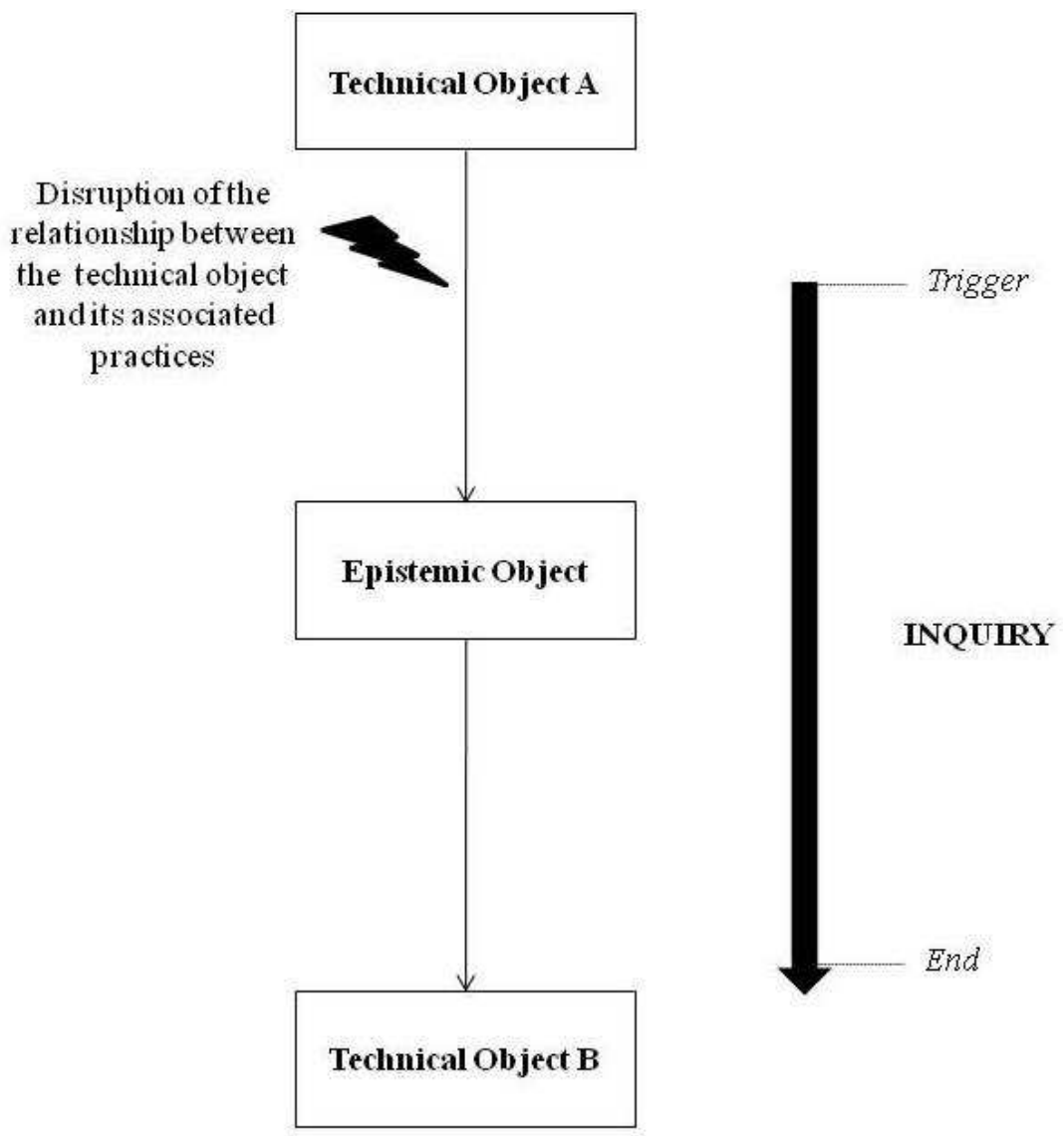

Figure 2.1: The Role of Objects in the Inquiry

\subsection{Proposal for a Theoretical Model}

The theoretical framework suggested in this section (cf. figure 2.2) argues that actors transform their practices in response to institutional change by transforming an epistemic object through a collective inquiry. Although this model is presented before the case study, it was designed throughout the study in an abductive way (Dewey, 1938; Peirce, 1931) (cf. Section 4). In particular, the model argues that institutional change disrupts actors' collective activity through disturbing the relationship between a technical object and its associated practices. This disruption triggers an inquiry, which aims to 
(re)build the 'usual' practices associated with the technical object. This occurs through the transformation of the technical object into an epistemic object.

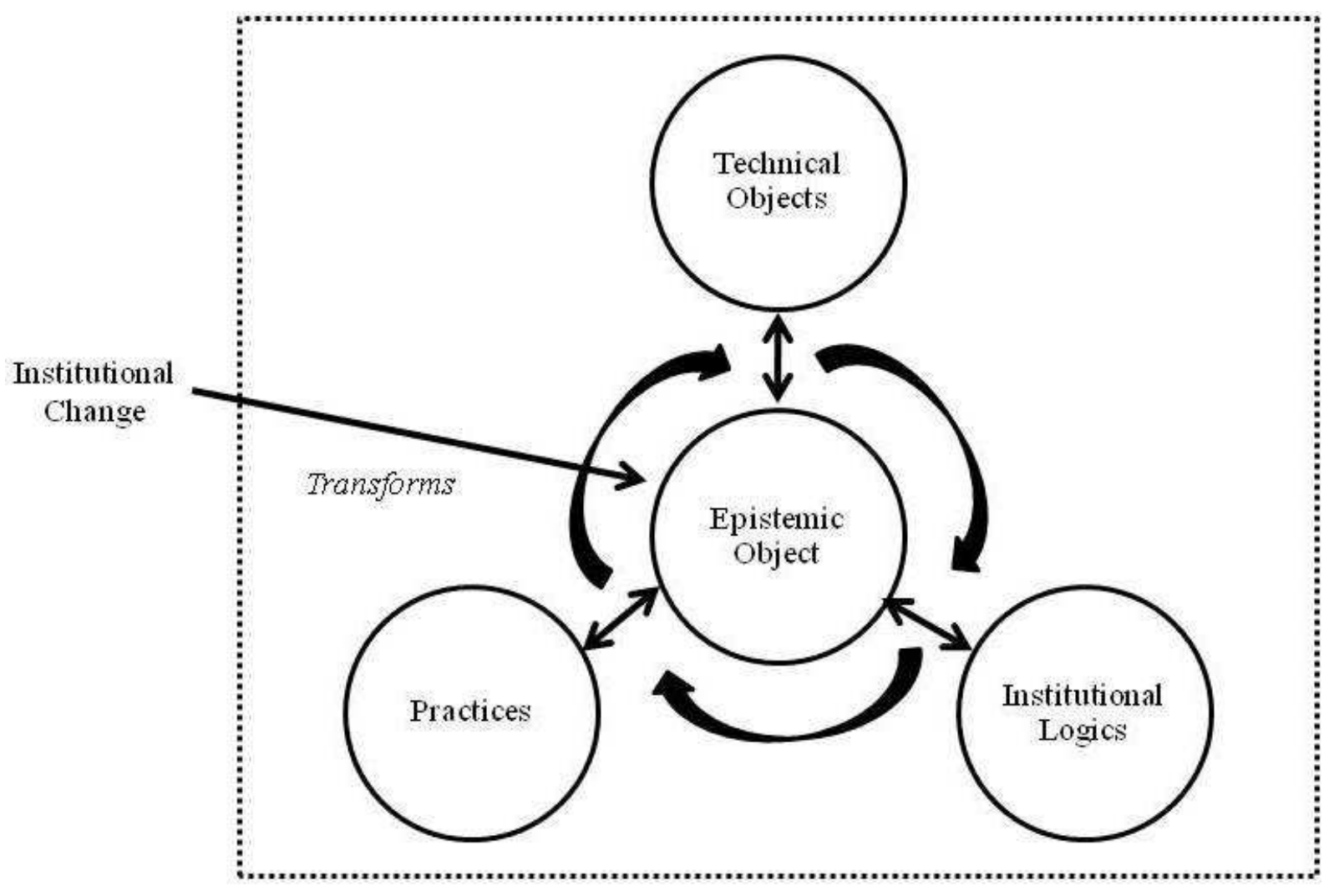

Collective Activity

Figure 2.2: The Mechanisms of Collective Inquiry

Actors use the epistemic object as a medium to transform their practices, institutional logics and technical objects (those which are not directly concerned by the disruption at stake in the inquiry). Namely, the epistemic object mediates this transformation through two roles:

1. It is a boundary object (Star \& Griesemer, 1989): a mediating instrument which enables and constrains the sharing of knowledge across actors.

2. It is a research object: a mediating instrument which allows the transformation of practices, institutional logics and technical objects.

Practices, institutional logics, technical objects, epistemic object are co-transformed through the collective inquiry and cannot be dissociated since institutional logics, technical and epistemic objects are all embedded in practice. Hence, how actors make sense in practice of the new institutions conveyed by institutional change results from the transformation of these five dimensions. Evidently, these four dimensions (practices, institutional logics, epistemic and technical objects) both constrain and enable the inquiry. For instance, while aiming to transform their practices in response to institutional change, actors may find the latter contradicts some of their previous institutional logics and find it difficult to transform their practices. The inquiry ends once the epistemic object is transformed into a technical object (cf. figure 2.1): the transformation of an epistemic object into a technical object enables actors to move from an indeterminate situation to a determinate one. Therefore, while institutional change is at the origin of the inquiry, the transformation of institutional logics is the output of the inquiry.

The following sections will explore in further detail these mechanisms by analyzing how an asset management company facing institutional change (re)designed its collective activity through transforming an investment process. 


\section{Case Study Features}

\subsection{What is SRI Mainstreaming?}

The institutional change under study in this article relates to SRI Mainstreaming which appeared in the French asset management sector a few years ago. It refers to the progressive integration of SRI criteria - such as environmental, social and governmental concerns - into conventional funds (i.e. traditional funds usually focused on financial performance). In 2009, while $90 \%$ of conventional funds in terms of assets integrated at least one SRI criterion, SRI funds as such represented only 2 to $3 \%$ of French assets under management. ${ }^{2}$ Two main elements explain the development of SRI Mainstreaming in France. Firstly, contrary to other countries, such as the United Kingdom and the United States, SRI has always followed a financial approach. Indeed, being developed over the past decade by asset managers and former financial analysts, SRI has conveyed the idea that better financial performance could be achieved in the long term by anticipating those costs linked to a below-average performance in social, environmental and governmental domains; a positive relationship which has not yet been borne out by evidence. Secondly, since 2002, the major French public pension funds - such as the FRR and the $E R A F P$ - have shown great interest in SRI; an attention which has played a major role in triggering the development of SRI among all French asset management companies.

As it develops, SRI Mainstreaming is progressively blurring the differences between SRI and the mainstream. Indeed, both SRI and conventional funds are now integrating SRI criteria in order to achieve better financial performance. Moreover, the SRI market is still unregulated: no public organization - such as the AMF (Autorité des Marchés Financiers) ${ }^{3}$-controls the content of SRI funds. In other words, any asset management company can claim its funds are SRI. However, despite their similar appearance, SRI funds can be distinguished from conventional funds in two major ways. Firstly, while the conventional funds concerned by SRI Mainstreaming integrate one or several SRI criteria, SRI funds usually draw on hundreds of SRI criteria. Secondly, contrary to conventional funds, SRI funds are often held accountable on the SRI aspects of their investment processes. In other words, they must explain to what extent they differ from conventional funds, while maintaining good financial performance. Nevertheless, over the past few years, asset management companies have been increasingly required to (re)design their SRI funds. They have been forced to differentiate their SRI funds from conventional ones to adapt to SRI Mainstreaming and have been encouraged to offer innovative SRI funds in order to face the intense competition which has appeared between SRI funds. Given that financial criteria may contradict SRI criteria in practice, this transformation of funds has been all the more difficult for asset management companies.

\subsection{The Company under Study}

\subsubsection{The Need for a Collective Inquiry}

The company under study, referred to as 'SRI Invest' ${ }^{4}$, is a small French asset management company - a subsidiary of one of the largest French mutual insurance companies - managing $€ 2$ billion and specialized in SRI since 1997. In 2007, SRI Invest faced a predicament: its SRI funds were judged archaic by the consultants responsible for invitations to tender. To address this problem, the CEO of SRI Invest - who arrived at the end of 2006 - decided to (re)design the company's SRI equity funds. For this purpose, he launched a working group, gathering seven representatives of the following Departments (an organizational chart is provided in figure 2.3):

- Sales: responsible for selling funds (two project managers).

\footnotetext{
2 This number only concerns OPCVM - Organismes de Placement Collectifs en Valeurs Mobilières (Organizations for Collective Investment in Transferable Securities). Source: www.novethic.fr

${ }^{3}$ French Securities Regulator

${ }^{4}$ SRI Invest is a pseudonym.
} 
- Asset Management: responsible for the financial aspects of funds (one asset manager and his assistant).

- SRI: responsible for the SRI aspects of funds (three SRI analysts).

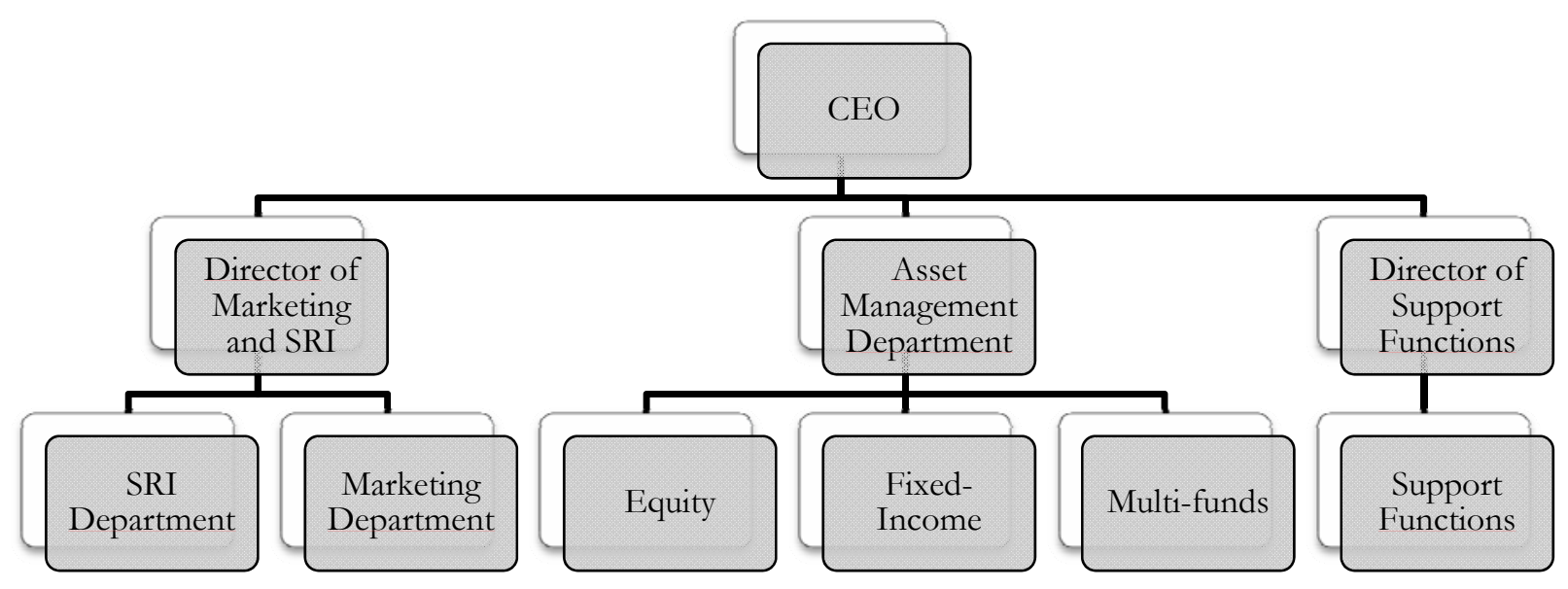

Figure 2.3: SRI Invest's Organizational Chart

The purpose of the working group was clear: to (re)design the SRI equity funds in order to meet both SRI demands and financial performance. Given that the three Departments depended on each other, the (re)design of funds had to be collective.

\subsection{The (re)Design of Collective Activity}

An SRI equity fund is an entity which collects money from different investors in order to invest it in shares. To achieve financial performance, an equity asset manager aims to select the companies whose share value is most likely to increase. A portfolio refers to the composition of the fund in terms of companies. A portfolio usually comprises between 40 to 50 companies, often the three to five best companies - financially and SRI speaking - in each sector. When investing, a client assesses a fund on four main aspects:

- Assets under management: they must be at least ten times bigger than the assets in which the client wants to invest.

- Financial performance: the fund must 'beat the market', which means that its financial performance must exceed the reference index and competitor fund performances.

- Administrative costs: the asset management company's fees must be the least expensive.

- Investment process: this describes the various stages through which companies are selected for the portfolio. The investment process must convince clients of the asset management company's ability to achieve better financial performance (i.e. its capacity to invest in companies whose share value is likely to increase). An investment process combines 1) actors' usual practices and 2) the physical representation of these practices, which can take the form of diagram, texts, and so on (cf. figures 2.4, 2.5 and 2.6 for examples).

When (re)designing a fund, an asset management company needs to (re)design the investment process of the fund. The investment process of an SRI fund usually follows a three-stage approach: 1) financial and SRI analysis; 2) the definition of an 'investment universe' which comprises all companies in which asset managers can invest and 3) decision criteria followed by asset managers to select companies in this investment universe. In other words, an investment process must explain the collective activity of the asset management company. The remainder of this article argues that actors use the representation of their investment process as an epistemic object to transform their collective 
activity - and thereby their technical objects, institutional logics and practices - in response to SRI Mainstreaming.

To gain a better understanding of the collective activity of SRI Invest, table 2.1 summarizes the main characteristics of the three types of actors who participated in the (re)design. In this particular case study, the institutional logics are identified to the professional logics of the three Departments (i.e. Asset Management, Sales and SRI).

\begin{tabular}{|c|c|c|c|}
\hline & Asset Managers & Project Managers & SRI Analysts \\
\hline Aim & $\begin{array}{l}\text { Maintaining good financial } \\
\text { performance. }\end{array}$ & $\begin{array}{l}\text { Selling funds, which } \\
\text { means receiving new } \\
\text { assets from investors. }\end{array}$ & $\begin{array}{l}\text { Favoring the most } \\
\text { socially responsible } \\
\text { companies. }\end{array}$ \\
\hline $\begin{array}{l}\text { Performance } \\
\text { Criteria }\end{array}$ & $\begin{array}{l}\text { - Financial performance of } \\
\text { funds, compared to their } \\
\text { peers and reference index } \\
\text { (assessed on a weekly } \\
\text { basis, except for bonuses } \\
\text { which are based on annual } \\
\text { performance). }\end{array}$ & $\begin{array}{l}\text { Number of assets obtained } \\
\text { from new investors during } \\
\text { the year. }\end{array}$ & $\begin{array}{l}\text { - Number of } \\
\text { companies analyzed } \\
\text { each year. } \\
\text { - Commitment to } \\
\text { business } \\
\text { development during } \\
\text { the year. }\end{array}$ \\
\hline $\begin{array}{l}\text { Main } \\
\text { Technical } \\
\text { Objects In- } \\
\text { Use }\end{array}$ & $\begin{array}{l}\text { - Financial models which } \\
\text { provide the best theoretical } \\
\text { composition of portfolios. } \\
\text { - Financial analyses } \\
\text { provided by brokers. }\end{array}$ & $\begin{array}{l}\text { - PowerPoint } \\
\text { presentations which } \\
\text { represent investment } \\
\text { processes. } \\
\text { - Track-record of the } \\
\text { company regarding } \\
\text { previous invitations to } \\
\text { tender. }\end{array}$ & $\begin{array}{l}\text { Social ratings } \\
\text { obtained from social } \\
\text { rating agencies. }\end{array}$ \\
\hline $\begin{array}{l}\text { Institutional } \\
\text { Logics }\end{array}$ & $\begin{array}{l}\text { - Financial background. } \\
\text { - They rely as much on } \\
\text { technical objects as on their } \\
\text { knowledge, experience and } \\
\text { intuition to select the } \\
\text { companies likely to be the } \\
\text { most profitable in the long } \\
\text { term. } \\
\text { - To achieve good financial } \\
\text { performance, they aim to } \\
\text { lower as much as possible } \\
\text { their constraints (including } \\
\text { SRI constraints). }\end{array}$ & $\begin{array}{l}\text { - Commercial } \\
\text { background. } \\
\text { - They need to understand } \\
\text { the job of asset managers } \\
\text { and SRI analysts to be } \\
\text { able to explain } \\
\text { investment processes to } \\
\text { clients in a simple and } \\
\text { 'attractive' way. } \\
\text { - They always look for } \\
\text { new ideas, new 'stories } \\
\text { to tell clients', which } \\
\text { may help them to } \\
\text { differentiate funds from } \\
\text { competitors'. }\end{array}$ & $\begin{array}{l}\text { - Ethical background } \\
\text { (CSR Departments, } \\
\text { social rating } \\
\text { agencies, trade } \\
\text { unions, NGOs, et } \\
\text { cetera.). } \\
\text { - They want to } \\
\text { change companies' } \\
\text { behavior through } \\
\text { asset management. } \\
\text { - They aim to be } \\
\text { informed on a daily } \\
\text { basis about the } \\
\text { companies they } \\
\text { analyze and to } \\
\text { constantly } \\
\text { strengthen the } \\
\text { importance of SRI } \\
\text { criteria in } \\
\text { investment } \\
\text { processes. }\end{array}$ \\
\hline
\end{tabular}




\begin{tabular}{l|l|l|l} 
& \multicolumn{1}{|c|}{ Asset Managers } & Project Managers & SRI Analysts \\
\hline Power & - They benefit from & - They are perceived as & - They lack power \\
significant power and & key actors for obtaining & and legitimacy. \\
legitimacy. & new assets. & - They are paid less \\
& - They are considered to & - Since they are & and are often \\
embody the 'value' of the & responsible for the & perceived as \\
& asset management & invitations to tender, & militants with little \\
company. & asset managers and SRI & awareness of \\
- SRI analysts and support & analysts must meet their & financial problems. \\
functions work for them. & demands. & - Nevertheless, they \\
& - However, asset & are also perceived \\
& managers and SRI & as key people to \\
& analysts often doubt & maintain the \\
& their technical & competitiveness of \\
& competences and & SRI funds and \\
& complain about their & participate in \\
& power regarding their & almost all company \\
& lack of technical & projects. \\
& legitimacy. & \\
& &
\end{tabular}

Table 2.1: Actors Characteristics

The interactions between actors are explored in further detail when analyzing the process of (re)design in section 5. The following section explains the research methods used to conduct the case study.

\section{Research Methods}

\subsection{Research Epistemology}

Accessing practices is a difficult task when conducting research. It requires a high level of integration of the researcher in the organization and a finely-shaded understanding of situations. Few methodologies enable this. In particular, methodologies following representational epistemologies which assume a correspondence between theory and reality - often mistake 'traces' of practices for practices (Lorino et al., 2010). On the one hand, they usually use mediating statements - such as documents or interviews - to access practices. On the other hand, they tend to describe reality as if it was an 'objective' thing; which leads researchers to miss the dialogical and dynamic relationships of practical actions. Consequently, the 'reflexive practices' by which actors make familiar commonplace activities of everyday life - their 'accounting practices' (Garfinkel, 1967) - are often disregarded. As Fox (2006) suggests:

Settings do not stand there ready-made and pre-defined but are made-up in situ ${ }^{5}$ by the same practices which make them accountable to the members.

Since the 'accounting practices' (Garfinkel, 1967) of actors can be 'known only in the doing' (Coulter, 1976), a researcher who aims to access practices needs to study the situations 'from the inside' and not 'from the outside' (Schotter, 2006). Unlike 'aboutness-thinking', this 'withness-thinking' (Schotter, 2006) implies sharing the 'accounting practices' of the social group under research. The researcher no longer observes practices but investigates them.

For this purpose, the researcher can conduct a pragmatist inquiry (Dewey, 1938; Peirce, 1931). According to pragmatism (cf. section 2.2), the objective of research is to offer an understanding for a purposeful action (Peirce, 1931). An inquiry is triggered by an 'existential unease' and differs from an

${ }^{5}$ Emphasized in the original text. 
automatic adaptation of practices based on conditioned reflex. It is verbalized, socialized and implies a distance between the inquiry participants and the object of the inquiry (i.e. its purpose). To investigate, the researcher mobilizes an abductive mode of reasoning, which interlaces narrative thinking, intuition and action (Peirce, 1931). Throughout, inquiry participants carry, use and transform mediations; which explains why the inquiry is both mediated and mediating (Lorino et al., 2010). The inquiry is a collective process made up of permanent dialogue between actors, whose differences nurture the investigation. Inquiry participants share and negotiate their understandings of situations along time (Schotter, 2006). The inquiry generates both new concepts and new practices (Lorino et al., 2010). The theoretical accounts of findings are deemed relevant once they are practically experimented. However, both practices and theories are temporary and fallible; they are always partial and can always be changed according to experience.

Following pragmatist epistemology, the article uses a cooperative inquiry method (Heron, 1996; Heron \& Reason, 1995), based on the concept of inquiry (Dewey, 1938; Peirce, 1931). A cooperative inquiry method 'involves two or more people researching a topic through their own experience of it, using a series of cycles in which they move between this experience and reflecting together on it' (Heron, 1996). The research process is described below.

\subsection{Research Process}

The case study is based on a three-year doctoral research project (2006-2009), conducted by the author. During these three years, I was involved in SRI Invest both as a researcher and as an SRI analyst. In particular, during the year of (re)design, I was at SRI Invest every day. Thanks to a CIFRE (Convention Industrielle de Formation par la Recherche en Entreprise) ${ }^{6}$ agreement - conducted between my laboratory, SRI Invest and myself, under the control of the French Ministry of Research I was permitted to use the data I collected through my position as an SRI analyst for academic purposes. According to the typology of membership roles of Adler and Adler (1987), I adopted the position of a complete member, which meant that I was 'fully immersed in the research setting'. This long and in-depth participative observation enabled me to understand the beliefs, values and goals of SRI Invest members. This position was both 'convert' and 'opportunistic' (Adler \& Adler, 1987). It was a 'convert' membership since I first decided to study SRI Invest, a company for which I was not previously working. However, it was also an 'opportunistic' membership in the sense that I did not expect this (re)design. Indeed, the new CEO of SRI Invest arrived six months after the beginning of my contract. Moreover, I discovered that SRI Invest was facing problems with its funds once I began to work as an SRI analyst.

During the year of (re)design (August 2007-July 2008), I supported my participative observation with day-to-day field notes. ${ }^{7}$ I described the main events of each day I spent at SRI Invest: meetings, e-mail, informal discussions, participation in invitations to tender and so on. Throughout, I discussed the process of (re)design with my SRI Invest colleagues and supervisors. At the beginning of 2008, I realized that SRI Invest was facing institutional change. I began to write narratives which described how actors (re)designed their practices and compared them to what was described in the literature. Rapidly, I identified the mechanisms of a pragmatist inquiry (Dewey, 1938; Peirce, 1931). After the (re)design, I left SRI Invest for six months to commit myself to research. During this period, I worked on the narratives and documentary evidence, such as minutes of the meetings, process presentations to clients (both working and final versions), responses to invitations to tender, and e-mails. On my return, I submitted a working version of this article to SRI Invest members and my supervisors in order to obtain their critical feedback for us to collectively agree on the findings. Regarding the enthusiasm of the company for the research project, I decided to interview all the members who participated in the (re)design. In February and March 2009, I conducted seven semi-structured interviews (six with the

\footnotetext{
${ }^{6}$ Industrial Contracts for Training Through Research

${ }^{7}$ This represented hundreds of pages of notes.
} 
working group members and one with the CEO), lasting between one and two hours. All interviews were tape-recorded and transcribed verbatim. For each stage of the (re)design, I asked each actor to explain to me in a retrospective way 1) their feelings, 2) what they understood of the situation, 3) how the (re)design concretely occurred, 4) why they acted in a certain way, 5) how they interpreted the reactions of other members, 6) if they thought it was a good choice. At the end of the interview, I asked them if they thought that the (re)design was successful and why, and which key events they remembered. In June 2009, I left SRI Invest to commit myself to research.

From April 2009 to April 2010, I wrote several versions of the paper - which I successively submitted to SRI Invest members and other researchers. I considered that my theoretical account of findings was relevant when both SRI Invest members and my supervisors agreed with the analysis. These research findings are presented in the next section.

\section{Case Study Findings}

This section describes and comments on the different stages of the (re)design using the pattern of inquiry developed by Dewey (1938) (cf. section 2.2.). Given that an inquiry is a continuous process and for clarification purposes, the first and the second stages of the pattern, on the one hand, and the third and the fourth stages, on the other, have been merged.

\subsection{Stages 1\&2: Indeterminate Situation and Institution of a Problem (August-September 2007)}

\subsubsection{Investment Process before the Inquiry}

In August 2007, SRI equity funds of SRI Invest were invested among the Dow Jones Eurostoxx 300, an index which represented 300 large, mid and small capitalization companies of 12 Euro zone countries. A quarterly SRI ranking of the companies in each activity sector was provided by SRI analysts to asset managers. This SRI ranking had not evolved since 1998 and was very simple: SRI grades provided by one social rating agency were summarized and balanced to provide an average SRI grade between 0 and 100 for each company. Asset managers followed the so-called best-in-class approach: in each sector, they favored companies with the best SRI grade, compared to their peers. To maintain good financial performance, the distribution of assets between sectors followed financial criteria, such as risk and diversification ratios. A monthly SRI grade was given to each portfolio - this consisted of assessing the average SRI grades of companies present in the portfolio. The SRI grade of each portfolio had to be over 50/100. If it was not the case, the asset manager was forced to change the content of his/her portfolio for the following month, although this never happened.

\subsubsection{A Doubtful Situation}

For an inquiry to begin, actors must face an uncertain and disturbing situation, as was the case for SRI Invest at this time. Due to the development of SRI Mainstreaming, an 'existential unease' had appeared inside the company: SRI funds were no longer competitive. Indeed, the reactions of clients and prospects when project managers - who arrived a few months before - submitted the investment process were clear:

1. The integration of SRI criteria in the company selection process was too superficial: more companies had to be excluded for SRI reasons only, a criterion known as 'SRI selectivity'.

2. The form of the SRI constraint (i.e. being above 50/100) was not sufficiently reliable. Indeed, this grade could be obtained by combining very good and very bad companies in the portfolio.

3. SRI criteria lacked innovation, compared to competitors.

At first, project managers thought that it was merely a problem of communication, although they had since changed their opinion. In September 2007, they believed that the investment process itself was 
problematic: SRI funds had to be transformed to meet new client and consultant demands. For this purpose and to restore a determinate situation, the CEO launched a collective inquiry, which took the form of a working group gathering representatives of the Sales, Asset Management and SRI Departments. The working group planned to meet on a weekly basis: an 'SRI committee' would be organized every Tuesday morning. The CEO explained:

Post-mortem assessments were no longer useful. [...] We had to think up new attractive products, which meant performance and originality in the presentation. The working group was launched for two reasons: we're cleverer when we work as a group and employees needed to appropriate the process. [...] It had to be a communal project. That's how it works best.

CEO, 2009

From then on, actors were encouraged to innovate by proposing new ideas. The working group would provide them with time and space for discussing their practices.

\subsection{Stages 3\&4: Determination of a Problem-Solution \& Reasoning (September 2007- January 2008)}

\subsubsection{Finding the Good Epistemic Object}

The first meeting took place in September 2007. Actors were somewhat 'lost' since they had never transformed a fund and did not know what to do. Asset managers and SRI analysts thought that project managers did not understand their job and vice versa. Actors aimed first at meeting their own demands and project managers took the lead of the group. Rapidly, the Sales Department realized that they needed something which could enable everybody to understand each other and mediate the inquiry; in other words, an epistemic object. They decided to work on 'company factsheets', which would summarize the SRI and financial profile of each company. Indeed, despite what they had previously said, project managers maintained the belief that SRI Invest needed only to prove its expertise and meetings were heated during the first few weeks. Rapidly, the company factsheets revealed themselves to be a bad epistemic object. After one and half months, the working group reached a deadlock: SRI analysts and asset managers did not succeed in designing the factsheets. According to them, factsheets could not be designed without (re)thinking the investment process itself:

The company factsheets were merely for commercial purpose. [...] We completely disagreed. Sales managers really needed them as a commercial tool. Whereas, for us [asset managers and SRI analysts], it was rather the opposite. It wasn't a tool, it was pure reporting. And, I must say, reporting with very little added-value. [...] It was completely of secondary importance.

Asset Manager, 2009

It was the worst thing we could have done! It was putting the cart before the horse. It was not triggered by the (re)design of the process but by the external motivation to demonstrate that we had a process which did not exist!

SRI Analyst, 2009

These two quotations demonstrate that the company factsheets were relevant neither for SRI analysts nor for asset managers. Being chosen by the Sales Department - according only to its own institutional logics - they did not enable the sharing of knowledge between actors. In other words, the company factsheets did not play an essential role for an epistemic object: being a 'boundary object' (Star \& Griesemer, 1989). According to the Director of Marketing \& SRI himself, this first choice was not a good one: 
Even today, working on the company factsheets is not easy. Frankly, these company factsheets have been a failure.

Director of Marketing \&SRI, 2009

This error illustrates that the identification of the technical object to be transformed into an epistemic object is not obvious. Finding the good epistemic object is part of the problem-solution stage, which is - according to Dewey (Dewey, 1938) - of major importance for the inquiry and a matter of delicacy.

In October 2007, the working group realized its mistake. They could not transform the funds without transforming their investment process. They decided to work on another epistemic object: the representation of the investment process (i.e. the PowerPoint presentations). For the first time, they represented their collective activity (cf. figure 2.4 ):

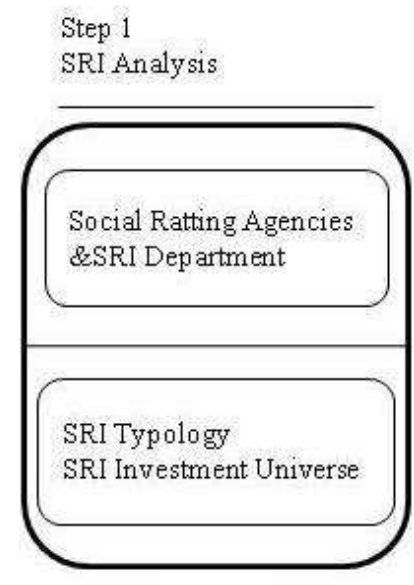

(a)

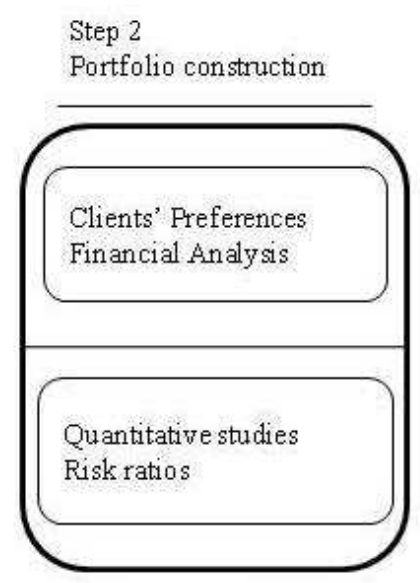

(b)

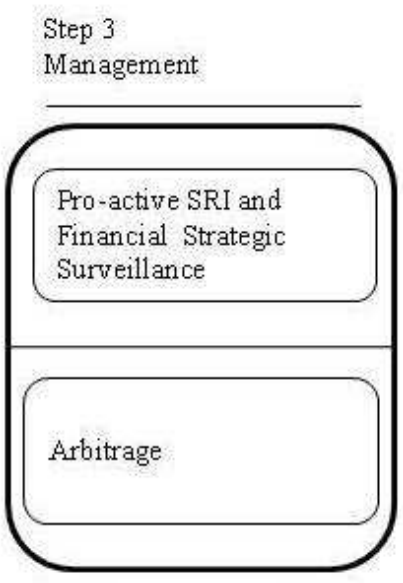

(c) gure 2.4: Investment Process (October 2007)

They identified three steps: a) the SRI analysis provided the investment universe; b) the portfolio was constructed according to the risk and diversification ratios chosen by clients; c) the asset manager selected companies so as to respect the SRI grade constraint and financial ratios; this included arbitrage which is the practice of taking advantage of a price difference between two or more markets. At the same time, they compared this investment process to competitors' processes and clients and consultants demands. They identified two problems they wanted to remedy: the asset manager lacked freedom when investing and insufficient companies were excluded for SRI reasons (i.e. which meant low SRI selectivity).

\subsubsection{Overcoming Contradictory Logics}

Now that they had agreed on a common problem, the main challenge for the working group was to overcome contradictory institutional logics at stake in the inquiry: the logics of the Asset Management, Sales and SRI Departments, respectively. The situation was all the more difficult since actors were looking for a synthesis of these three logics. Yet, SRI criteria and financial performance often contradicted each other and asset managers and SRI analysts did not always understand business demands. The priorities of each Department being different, actors faced major problems in achieving a collective agreement. As the following e-mail from an SRI analyst illustrates, the inquiry required efforts:

\footnotetext{
${ }^{8}$ Source : SRI Invest 


From: SRI Analyst $1^{9}$
Date: Friday $26 / 10 / 200719: 28$
To: Project Manager; SRI Analyst 2; Equity Asset Manager; Fixed-Income Asset
Manager
Cc: Director of SRI \& Marketing
Object: RE: Committee 23/10/2007
Hi,
For the next committee, I think that it would be useful to come back to the
definition of our priorities and working methods. To date, we have agreed on some
priorities: 1) company factsheets, 2 ) sector analyses, 3) investment process.
However, there are also other priorities we could consider: 4 ) annual meetings, 5 )
shareholder activism and 6) suppliers' analysis.
Too many priorities: no more priority. Today, everybody does what he/she
wants or chooses what he/she considers to be the major priority, evidently at the
expense of others. Choices are not always the same. Since everybody behaves the
same way, we come up with scattered outputs which are very difficult to
consolidate and to account for in a coherent way. Moreover, I am sometimes
surprised that what is required for display concerns (let's say for marketing
purposes) quickly becomes the content of our solution which contradicts what is
required.
To celebrate the festive season with the impression of having gone one step
further in our project, I think that it would be useful to report on the project's
progress at the next committee meeting, scheduled for the $6 / 11$. Based on my
personal experience, this is necessary to avoid personal (often barely perceptible)
and collective problems we could risk facing.
Best wishes,
SRI Analyst 1

This synthesis required time, mutual understanding and a capacity to transform practices, institutional logics and technical objects according to institutional change and to the priorities of each Department. In particular, the project manager tried to take advantage of his cross-border position to facilitate the achievement of a compromise between the logics of the three Departments:

I tried to reconcile each party's interests, which were evidently different: SRI purists; asset managers without regret and the Director of Marketing \& SRI who really wanted to show that the process was, in fact, simple, robust and immutable.

Project Manager, 2009

\subsubsection{Transforming Collective Activity through the Epistemic Object}

To reach a compromise, inquiry participants took the diagram of the investment process (cf. figure 2.4) as an epistemic object and set up a white board for each actor to physically transform the investment process. Over the course of a few weeks, the working group attempted to (re)design the three stages $(\mathrm{a}, \mathrm{b}$ and $\mathrm{c})$ of the investment process. Arrows were added, new stages appeared, others disappeared, names changed and so on. Each actor reacted to the proposed changes from his/her perspective. In November 2007, they had come up with a new schema (cf. figure 2.5).

\footnotetext{
${ }^{9}$ At this moment of the inquiry, there were only two SRI analysts, the third one arrived at the beginning of 2008.
} 


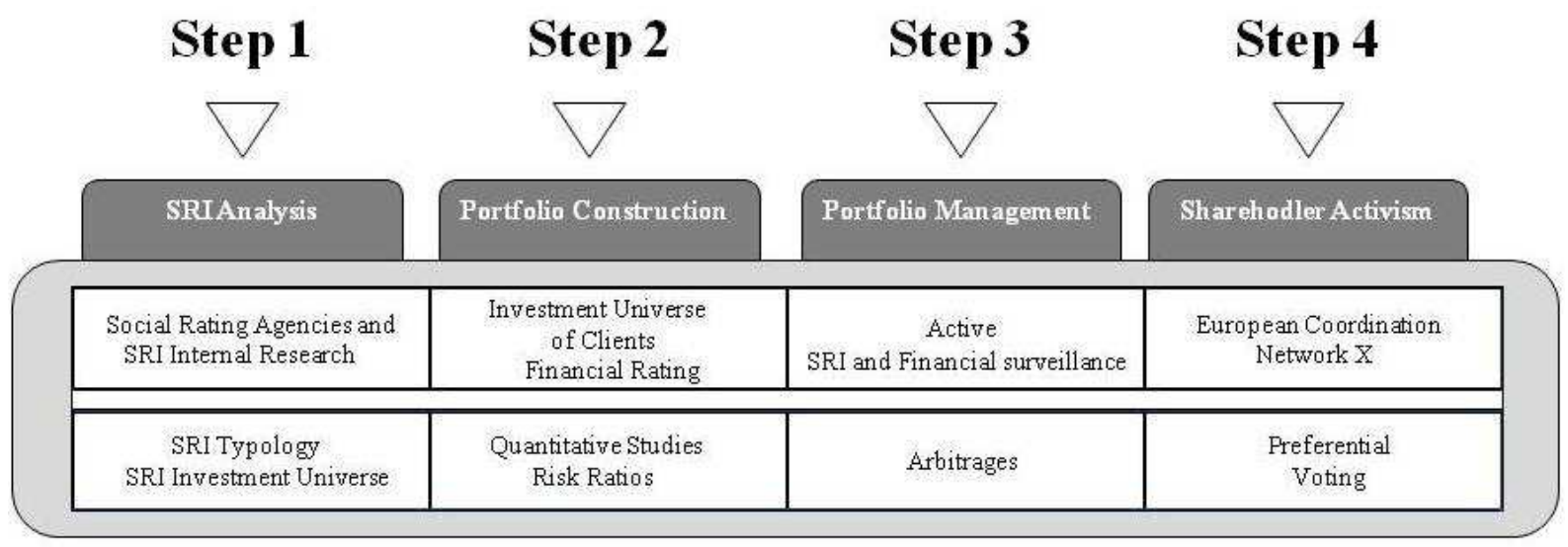

Figure 2.5: Investment Process (November 2007) ${ }^{10}$

However, this new investment process did not remedy the problems. Indeed, the first three steps had hardly changed. The main change was the addition of a fourth step concerning shareholder activism, which related to the use of equity stakes in a corporation to put public pressure on its management (referred to in the step 4 of the figure 2.5 as preferential voting). Further work was required and the working group decided to keep transforming its epistemic object. As the schema evolved, project managers submitted it to prospects to obtain their feedback. Throughout, constant round trips were made between reasoning and experimentation:

The problem was that we needed to sell the funds as we created them. This led to many tensions in the working group, notably in terms of timing. We submitted the presentation to a prospect one day, and the following day, we had to (re)design the process. [...] Each time I came back with new questions we needed to answer.

Project Manager, 2009

Gradually, actors transformed their institutional logics, technical objects and practices. The transformation of the investment process raised new questions: 'Which criteria must be selected?', 'What is the purpose of SRI?', 'What do we do if financial and SRI criteria contradict one other?' Each Department worked on its part of the process: asset managers worked on financial criteria, SRI analysts on SRI criteria and project managers on the PowerPoint presentations. Many informal discussions occurred, but every week, each actor had to submit to the others his/her proposals during the SRI committee meeting. Discussions continued to take place about each actor's hypothesis. Notably, these weekly meetings enabled all members to acquire the same level of information and to set deadlines. They organized the inquiry by giving each actor his/her chance to speak:

The more we developed the process, the more we rationalized the debates inside the committee: we stopped talking about everything and became much more organized. Once this process had been launched, everybody could go back to his/her job: asset managers to asset management and SRI analysts to SRI.

Asset Manager, 2009

As the research process unfolded, the institutional logics of actors converged to SRI Mainstreaming: SRI criteria were selected according to their impact on business while the working group agreed to exclude companies for SRI reasons. The adoption of this logic was a way for each Department to meet its requirements: SRI selectivity, financial performance and innovative processes. Indeed, companies assessed negatively on SRI aspects were also expected to rate negatively on financial aspects. However, this choice also resulted from personal convictions, since the asset manager defined himself as an SRI asset manager, SRI analysts became increasingly attuned to financial logics and the project

${ }^{10}$ Source : SRI Invest 
managers believed that SRI funds were good 'stories to tell clients'. These changes were also driven by the solidarity which existed in the working group: actors wanted to succeed. It was also a strategic choice, which followed institutional change itself. As the working group submitted its investment process to prospects and consultants, it realized that SRI Mainstreaming was expanding into asset management.

The working group progressively made sense of SRI Mainstreaming: SRI criteria had to be of assistance in selecting the most socially responsible companies. Consequently, asset managers and SRI analysts needed to find SRI criteria which impacted business. To do so, they had to transform the technical objects they used: a new SRI data-base was created and econometric tests were carried out. Through transforming their epistemic object, actors generated new technical objects:

We decided to create an SRI data-base because we were all aware that with the new process, we needed to build new tools; I would call them decision-making tools. They needed to be somewhat industrialized and automatic.

Asset Manager, 2009

However, financial performance was not sufficient. The working group also had to differentiate their SRI funds from conventional ones and thought that this could be achieved through high SRI selectivity - which related to the number of companies excluded only for SRI reasons - and which was widely used by consultants to assess funds.

In January 2008, practices were transformed according to SRI Mainstreaming: SRI criteria were deemed as important as financial criteria in generating financial performance. The working group had a new investment process (cf. figure 2.6) based on a decision matrix (cf. figure 2.7) as well as new company assessment factsheets (cf. appendix 1).

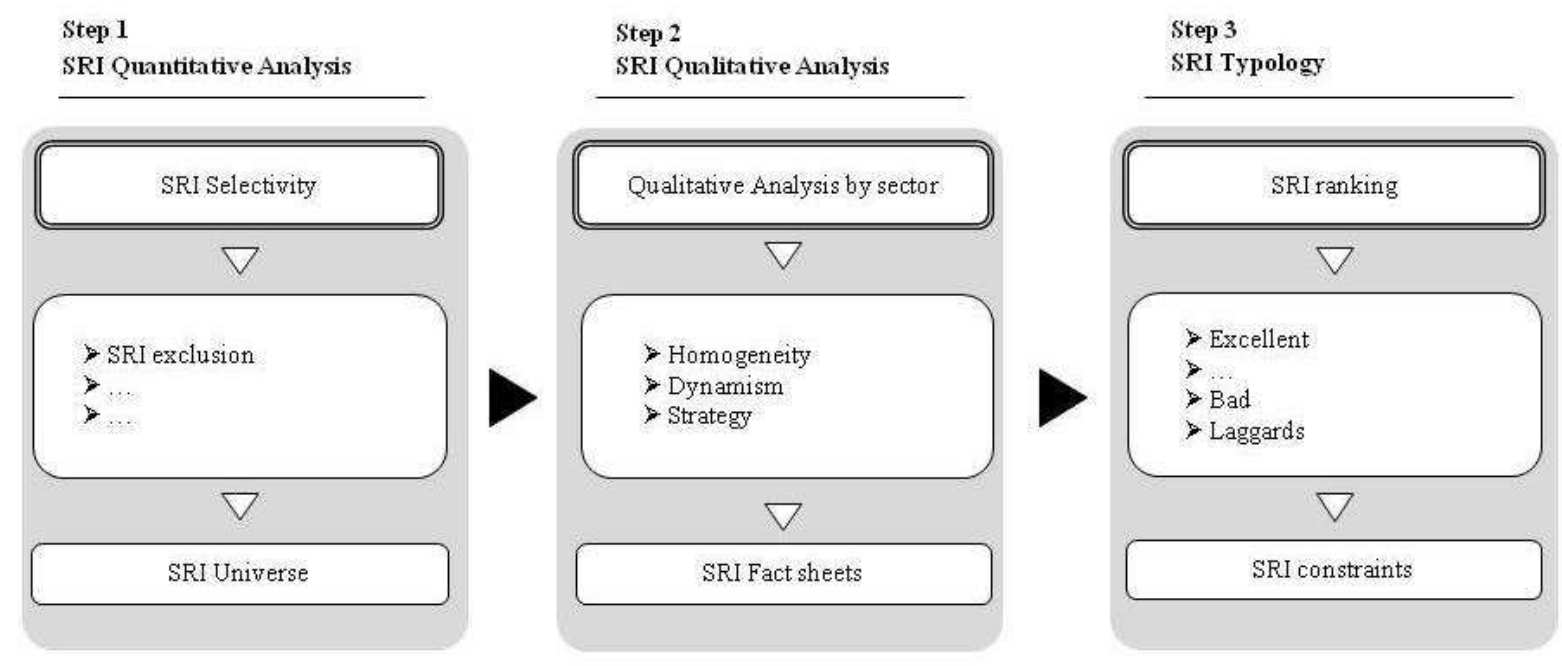




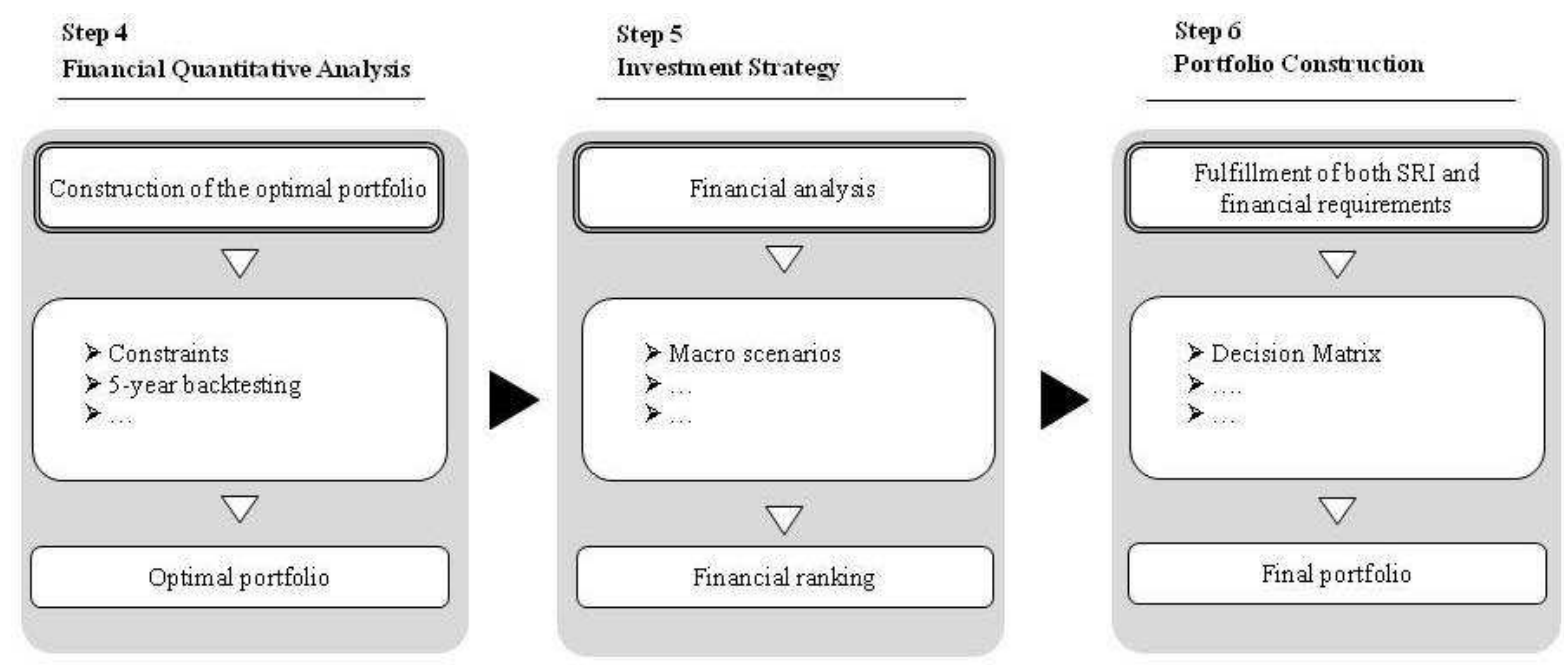

Figure 2.6: Investment Process (January 2008) ${ }^{11}$

\begin{tabular}{|c|c|c|c|c|c|c|}
\hline & \multicolumn{5}{|c|}{ SRI PROFILE OF THE COMPANY } \\
\hline & & Excellent & $\ldots$ & Average & $\mathrm{Bad}$ & Laggards \\
\hline \multirow{5}{*}{ 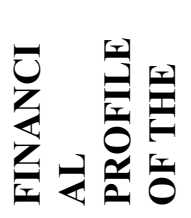 } & Excellent & & & & & \\
\hline & $\cdots$ & & & & & \\
\hline & Average & & & & & \\
\hline & $\mathrm{Bad}$ & & & & & \\
\hline & Laggards & & En & & & \\
\hline
\end{tabular}

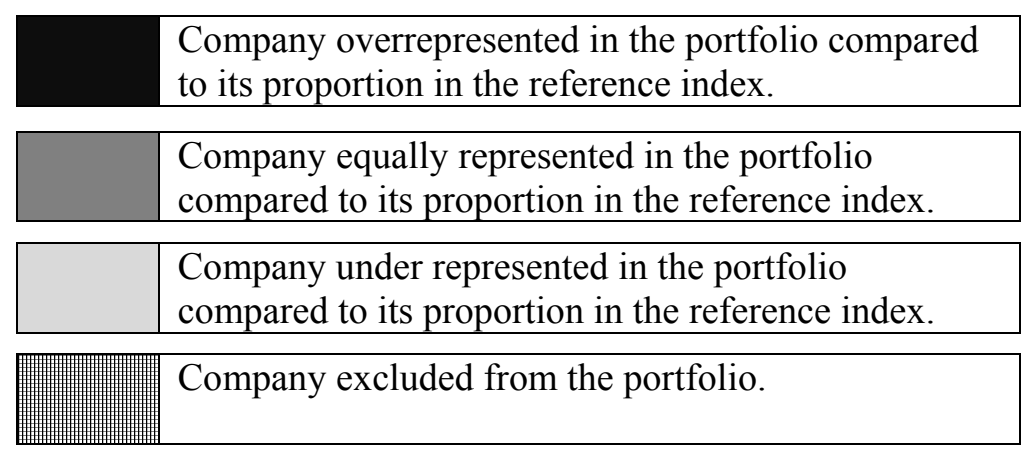

Figure 2.7: Decision Matrix (January 2008) ${ }^{12}$

SRI analysis was much more complex and stemmed from the grades of three social rating agencies and SRI analysts' analyses. Companies were ranked through a decision matrix according to their SRI and financial ranking. Companies with the best SRI and financial profile would be overrepresented in the portfolio. Companies with an excellent SRI profile but a very bad financial profile, and vice versa, would be excluded (cf. figure 2.7). Other companies would be selected according to their SRI and financial profile. SRI selectivity (i.e. the category 'SRI laggards') was expected to represent $50 \%$ of the investment universe.

\subsection{Stage 5: The Operational Character of Facts-Meanings (January-July 2008)}

In January 2008, the investment process had been re-designed 'on paper', but was not yet implemented. Indeed, the inquiry could not end until both facts and ideas were recognized as

\footnotetext{
${ }^{11}$ Source : SRI Invest

${ }^{12}$ Source : SRI Invest 
operational. Consequently, the working group first decided to conduct 'back-testing' (i.e. testing the new investment processes on fictitious portfolios) under the supervision of asset managers. As this was a first time experience, they faced a number of unexpected problems including the choice of software, the selection of technical constraints and so on. As a result, the back-testing took more time than originally planned. However, during the entire period, actors met on a weekly basis to discuss the problems faced by asset managers. Moreover, whereas existing funds did not follow the new investment processes, actors behaved as if the new process were already implemented. Thus, project managers sold the new process and asset managers and SRI analysts discussed company ratings using their new criteria. Practices, institutional logics and technical objects of the working group were already transformed in response to institutional change. Throughout, actors continued to change the investment processes. As an SRI analyst explained:

When designing a process, we implement it and we wait for the feedback from asset managers. If we realize that the asset manager is too limited when investing, we change SRI selectivity.

SRI Analyst, 2009

Once it was transformed according to these insufficiencies, the epistemic object suggested new insufficiencies which, in turn, guided the research process. The SRI analyst continued:

When you provide an asset manager with a ranking, he/she tells you that there is a problem. So it makes you study the ranking. In doing so, you identify other problems in the analysis, thought it was not your first purpose. You shouldn't have found this mistake. But, by solving one problem, you created another one.

SRI Analyst, 2009

The new investment process was finally implemented in May 2008. However, two weeks later, the $50 \%$ SRI selectivity raised major problems: too many companies still had a contradictory SRI and financial profile. A 50\% SRI selectivity threatened financial performance. Hence, the epistemic object kept suggesting where to investigate through the insufficiencies it displayed. Facing these problems, inquiry participants decided to continue to transform the investment process. However, this decision was not easy to make for the group: several actors were afraid of lacking the courage to continue the investigation. The inquiry kept demanding efforts:

There comes a moment when I'm afraid because I can sense lassitude; this happened at the end of the first term of 2008. I saw that guys were dragging their feet, that some of them no longer attended meetings. We no longer knew what to do: one day, we did one thing, the next day, another. [...] To my mind, we were steering off course, although we did finally get back on track.

Director of Marketing \& SRI, 2009

This inquiry continued back and forth between reasoning and experimentation. Throughout this long and unpredictable process, the investment process matured. In June 2008, the working group decided to lower SRI selectivity to $40 \%$, then $25 \%$. In July 2008 , the working group officially finished the task and the new investment process seemed to work in practice. The inquiry was interrupted when the working group - and more particularly the CEO - judged that the epistemic object was sufficiently transformed; at least enough to become convincing and commercially effective. The CEO comments:

There comes a moment when you have to stop looking for something else, since it's no longer useful - you don't find anything further... It's a bit like doing research. But I don't have to tell you that, do I? There comes a moment when you have something that you shouldn't try to improve. You must go with it and then... carry on.

CEO, 2009 
Nevertheless, certain actors complained about the superficial aspect of the (re)design. They felt that they did not have enough time to (re)design the process. This was highlighted by the following remark made by an asset manager:

Sales wanted to implement something quickly because they had time constraints. Regarding SRI and financial aspects, we didn't have the same time-scale since it was obvious that we couldn't fail. We couldn't launch a new process without having previously tested it. [...] Finally, the time constraint won out. It conveyed a pragmatic and industrial approach, at least on the quantitative aspects.

Asset Manager, 2009

In other words, time constraints forced the working group to finish the (re)design though the resulting technical object was not judged fully relevant by all actors. Despite this, the new investment process was accepted from then on; it became a technical object whose associated practices were considered as the (new) usual ones.

\subsection{Epilogue (January 2010)}

The fact that an epistemic object has been transformed into a technical object does not mean that the inquiry is perceived as successful by inquiry participants. In fact, success differed according to actors' view points. In January 2010, one and half years after the (re)design, all working group members agreed on at least one success of the inquiry: they transformed their collective activity in response to SRI Mainstreaming. A discussion with the asset manager illustrated this point:

AUTHOR: Would you say that it [the process of (re)design] has been a success?

ASSET MANAGER: It's a bit early to say so, but if we consider how inexperienced the team was and the challenge involved, which I find, was no mean feat, and if I take the short track-record we have today, then yes, we've succeeded. [...] We worked very hard on this process. We really did our best.

In particular, members were very proud of having overcome contradictory logics. Indeed, project managers, SRI analysts and asset managers were now working together through the new investment process. They were all convinced that SRI criteria would generate financial performance in the long term although they still lacked the time to prove it.

Regarding business success, the outcomes were contradictory. On the one hand, the investment process was recognized as being one of the most inventive processes of the sector. Indeed, in September 2009, SRI Invest was among the 97 funds (among the 250 funds listed) to obtain the 'SRI label' of Novethic, whose goal is to boost the development of SRI in France. Furthermore, SRI Invest was one of four funds (among the 87 which obtained the SRI label) to receive the 'SRI criteria' label, which rewards those funds considered to be the most innovative in terms of SRI. On the other hand, the new investment process was not a major success among clients. Notably, the lack of innovation of the investment process perceived by clients participated in this commercial failure. Regarding competitors, the investment process was not deemed to be sufficiently innovative to compensate for the lack of assets and experience. Other factors also contributed to this: the limited number of assets under management, the lack of experimentation of the new investment process and the financial crisis which favored fixed-income over equity funds. Consequently, the future of SRI Invest was from then on compromised. A few months before, a takeover threat appeared and SRI Invest members were encouraged to find another job. It seemed that the parent company no longer wanted to keep the subsidiary. 


\section{Discussion and Conclusions}

\subsection{Theoretical Contributions}

The article shows that logics and practices are transformed through the transformation of objects. The detailed description of how a working group (re)designed an equity investment process in response to new demands for SRI gives strong support for this assumption. By exploring the process of transformation of logics itself, the article offers new perspectives on the mechanisms of the transformation of logics in practice. Namely, it demonstrates that objects - in this case, market devices - play a key role in the transformation of logics by providing actors with a medium through which transforming their logics and practices. This is possible thanks to the double status of objects as 'technical' and 'epistemic,' which both enable and constrain the transformation of logics (i.e. maintain previous logics while enabling their transformation).

By exploring the process of institutional change itself, the article has offered new perspectives on the mechanisms of institutional change in practice. Namely, it has demonstrated that institutional change disrupts collective activity through disrupting the relationship between a technical object and its associated 'usual' practices; which transforms the latter into an epistemic object. Thanks to a collective inquiry, actors aim to transform the epistemic object back to a technical object in order to restore day-to-day practices. Throughout, they transform their collective activity, practices, technical objects and institutional logics in response to institutional change. Thus, the article has argued that while institutional change has triggered the inquiry, it has not directly transformed institutional logics. Instead, the transformation of institutional logics has been an output of the inquiry.

In demonstrating this, the article expands previous research on logics by directly examining the transformation of logics within an organization. Regarding the lack of intellectual relationships between institutional theories, on the one hand, and practice theories, on the other, this topic is a key one for understanding institutional change in practice. In particular, over the past few years, this bridging between practice and institutional theories has been frequently required from both institutional scholars (Lounsbury \& Crumley, 2007; Powell \& Colyvas, 2008) and practice scholars (Weick, 1995). Furthermore, the article enriches previous research by focusing on the role of objects in the transformation of logics, a topic which has been little researched until now (Friedland, 2009; Kaghan \& Lounsbury, 2005; Miller, 2008; Spee \& Jarzbkowski, 2009). This furthers our understanding of how actors embody and transform their logics and practices through epistemic objects. Nevertheless, other studies of institutional change in practice are needed to generalize these findings more broadly.

Regarding SRI, this article is among the few studies that have analyzed the workings of an asset management company in practice and the impacts of new demands for SRI on asset management practices. Notably, this is explained by the fact that the phenomenon of SRI is very recent and still ongoing. Given that SRI Mainstreaming is from now on a major topic for asset management worldwide (Robecco \& Booz, 2008), this article may help us to understand and predict the expected impacts of SRI demands on the financial sector.

\subsection{Methodological Contributions}

By using a non-representational epistemology, based on the pragmatist concept of inquiry (Dewey, 1938; Peirce, 1931), the article has aimed to enrich methodologies following representational epistemologies (Lorino et al., 2010). Notably, this methodology has enabled accessing the complexity of practices by exploring not only what was directly observable but also the processes of their transformation. In doing so, the article has demonstrated that pragmatist methods, such as the cooperative inquiry method (Heron, 1996; Heron \& Reason, 1995), enable researchers to access the everyday practices of actors. When a researcher investigates a situation, instead of observing it, he/she is more likely to understand the 'accounting practices' of actors (Garfinkel, 1967). In particular, this 
epistemological position is all the more important when researchers aim to understand the process of change itself. In addition, the article has offered methodological insights on pragmatist research. Regarding the growing interest for pragmatism over the past few years (Lukka \& Modell, 2009; Simpson, 2009), this use of a cooperative inquiry method could be valuable for further research.

\subsection{Limitations and Perspectives}

Three limitations of the study call for further research. Firstly, it was difficult to determine from the case study whether the change in institutional logics at the company level concerned the sector as a whole. On the one hand, lack of time prevented me from assessing the long-term impacts of institutional change on practices, and on the other, the study of other asset management companies would have been necessary to be able to argue that institutional logics were transformed at the sector level. Secondly, the article did not explore whether the transformation of practices impacted institutional change. This effect could have occurred in three main ways: 1) the transformation of client demands (i.e. change in the offer); 2) the transformation of asset managers' practices (i.e. change in the sector) and 3) the transformation of standards (i.e. change in SRI norms, for instance SRI labels). Moreover, interactions between SRI Invest and the rest of the sector were not explicitly examined, which may convey the idea of an armchair (re)design. Yet, the working group members constantly interacted with their environment throughout the process. Further work is needed to account for these relationships. Lastly, given the financial crisis and other organizational elements, such as the lack of assets, the study was not able to fully assess the impacts of the inquiry on practices. In other words, it was difficult to determine whether the inquiry was successful. 


\section{REFERENCES}

Abernethy, M. A., \& Chua, W. F. 1996. A Field Study of Control System "Redesign": The Impact of Institutional Processes on Strategic Choice. Contemporary Accounting Research, 13: 569606.

Adler, P. A., \& Adler, P. 1987. Membership Roles in Field Research. Newbury Park CA: Sage Publications.

Barley, S. R. 2008. Coalface Institutionalism. In R. Greenwood, C. Oliver, K. Sahlin, \& R. Suddaby (Eds.), The Sage Handbook of Organizational Institutionalism: 490-515. London: Sage.

Basu, O. N., \& Dirsmith, M. W. 1999. The Coupling of the Symbolic and the Technical in an Institutionalized Context: The Negociated Order of the GAO's Audit Reporting Process. American Sociological Review, 64: 506-529.

Bogt, H. J. T., \& Scapens, R. W. 2009. Performance Measurement in Universities: A Comparative Study of Two A\&F Groups in the Netherlands and the UK. SSRN Working Paper $n^{\circ} 1432749$.

Brusson, N. 2002. The Organization of Hypocrisy: Copenhagen Business School Press.

Burns, J., \& Scapens, R. W. 2000. Conceptualizing Management Accounting Change:An Institutional Framework. Management Accounting Research, 11(1): 3-25.

Callon, M., Millo, Y., \& Muniesa, F. 2007. Market Devices. Oxford: Blackwell Publishing.

Carlile, P. 2002. A Pragmatic View of Knowledge and Boundaries: Boundary Objects in New Product Development. Organization Science, 13(4): 442-455.

Coulter, J. 1976. The Ethnomethodological Programme in Contemporary Sociology. The Human Context, 6(1): 103-122.

Dambrin, C., Lambert, C., \& Sponem, S. 2007. Control and Change - Analysing the Process of Institutionnalisation. Management Accounting Research, 18: 172-208.

Dewey, J. 1938. Logic: The Theory of Inquiry (Saerchinger ed.): Henry Holt and Company.

DiMaggio, P. J., \& Powell, W. W. 1983. The Iron Cage Revisited: Institutional Isomorphism and Collective Rationality in Organizational Fields. American Sociological Review, 48(2): 147160.

DiMaggio, P. J., \& Powell, W. W. 1991. Introduction. In W. W. Powell, \& P. J. DiMaggio (Eds.), The New Institutionalism in Organizational Analysis: 1-38. Chicago, IL: University of Chicago Press.

Fox, S. 2006. 'Inquiries of Every Imaginable Kind': Ethnomethodology, Practical Action and the New Socially Situated Learning Theory. The Sociological Review, 55(3): 426-445.

Friedland, R. 2009. Institution, Practice and Ontology: Towards A Religious Sociology. In R. E. Meyer, K. Sahlin, M. J. Ventresca, \& P. Walgenbach (Eds.), Institutions and Ideology: Emerald.

Friedland, R., \& Alford, R. R. 1991. Bringing Society Back In: Symbols, Practices and Institutional Contradictions. In W. W. Powell, \& P. J. DiMaggio (Eds.), The New Institutionalism in Organizational Analysis: 232-263. Chicago: University of Chicago Press.

Garfinkel, H. 1967. Studies in Ethnomethodology (Second ed.): Paradigm Publishers.

Hasselbladh, H., \& Kallinikos, J. 2000. The Project of Rationalization: A Critique and Reappraisal of Neo-Institutionalism in Organization Studies. Organization Studies, 21(4): 697-720.

Heron, J. 1996. Co-Operative Inquiry: Research into the Human Condition. London: Sage.

Heron, J., \& Reason, P. 1995. Co-Operative Inquiry. In R. Harre, J. Smith, \& L. Van Langenhove (Eds.), Rethinking Methods in Psychology London: Sage.

Hopper, T., \& Major, M. 2007. Extending Institutional Analysis through Theoretical Triangulation: Regulation and Activity-Based Costing in Portuguese Telecommunications. European Accounting Review, 16(1): 59-97.

Jarzbkowski, P. 2004. Strategy as Practice: Recursiveness, Adaptation and Practices-in-use. Organization Studies, 25: 529-560.

Kaghan, W. N., \& Lounsbury, M. 2005. Artifacts, Articulation Work, and Institutional Residue. In A. Rafaeillli, \& M. Pratt (Eds.), Artifacts and Organizations: Lawrence Earlbaum Associates. 
Knorr-Cetina, K. 1995. Laboratory Studies: The Cultural Approach to the Study of Science. In S. Jasanoff, G. E. Markle, J. C. Peterman, \& T. Pinch (Eds.), Handbook of Science and Technology Studies. Thousands oaks London \& New Delhi: Sage.

Knorr-Cetina, K. 1997. Sociality with Objects. Social Relation in Postsocial Knowledge Societies. Theory, Culture and Society, 14(4): 1-31.

Kostova, T., \& Roth, K. 2002. Adoption of an Organizational Practice by Subsidiaries of Multinational Corporations: Institutonal and Relational Effects. Academy of Management Journal, 45(1): 215-233.

Latour, B. 1987. Science in Action: How to Follow Scientists and Engineers Through Society: Open University Press.

Lorino, P. 2006. The Instrumental Genesis of Collective Activity - The Case of an ERP Implementation in a Large Electricity Producer OLKC 2006 Conference at the University of Warwick, Coventry.

Lorino, P., Tricard, B., \& Clot, Y. 2010. Research Methods for Non-Representational Approachs of Organizational Complexity. The Dialogical and Mediated Inquiry. Organization Studies, Forthcoming.

Lounsbury, M. 2001. Institutional Source of Practice Variation: Staffing College and University Recycling Programs. Administrative Science Quartely, 46: 29-56.

Lounsbury, M. 2008. Institutional Rationality and Practice Variation: New Directions in the Institutional Analysis of Practice. Accounting, Organizations and Society, 30: 735-764.

Lounsbury, M., \& Crumley, E. T. 2007. New Practice Creation: An Institutional Perspective on Innovation. Organization Studies, 28(7): 993-1012.

Lukka, K., \& Modell, S. 2009. Validation in Interpretative Management Accounting Research. Accounting, Organizations and Society, Available on line.

MacKenzie, D. 2006. An Engine, Not a Camera - How Financial Models Shape Markets: MIT Press.

MacKenzie, D., \& Millo, Y. 2003. Constructing a Market, Performing Theory: The Historical Sociology of Financial Derivatives Exchange. American Journal of Sociology, 109(1): 107145.

Meyer, J. W., \& Rowan, B. 1977. Institutional Organizations: Formal Structure as Myth and Ceremony. American Journal of Sociology, 83: 340-363.

Miller, P. 2008. Figuring out Organizations. Paper for Presentation at Nobel Symposium “Foundations of Organization”, Grand Hotel Saltsjöbaden, Sweden, 28-30 August, 2008.

Miller, P., \& O'Leary, T. 2007. Mediating Instruments and Making Markets: Capital Budgeting, Science and the Economy. Accounting, Organizations and Society, 32: 701-734.

Oliver, C. 1991. Strategic Responses to Institutional Processes. Academy of Management Review, 16 : 145-179.

Peirce, C. S. 1931. Collected Papers of Charles Sanders Peirce. Cambridge MA: Belknap Press or Harvard University Press.

Powell, W. W., \& Colyvas, J. A. 2008. Microfoundations of Institutional Theory. In R. Greenwood, C. Oliver, R. Suddaby, \& K. Sahlin (Eds.), The SAGE Handbook of Organizational Institutionalism. London: Sage.

Rheinberger, H.-J. 1992. Experiment, Difference, and Writing: I. Tracing Protein Synthesis. Studies in History and Philosophy of Science, 23(2): 305-331.

Rheinberger, H.-J. 1997. Toward a History of Epistemic Things: Synthetizing Proteins in the Test Tube. Stanford, CA: Stanford University Press.

Robecco, \& Booz. 2008. Responsible Investing: a Paradigm Shift From Niche to Mainstream. Robecco and Booz \& Company Studies.

Sahlin, K., \& Wedlin, L. 2008. Circulating Ideas: Imitation, Translation and Editing. In R. Greenwood, R. Suddaby, \& K. Sahlin (Eds.), The SAGE Handbook of Organizational Institutionalism: $218-242$.

Schotter, J. 2006. Understanding Process from Within: An Argument for 'Witness'-Thinking. Organization Studies, 27(4): 585-604.

Scott, R. W. 2001. Institutions and Organizations. Thousand Oaks, CA.: Sage Publications. 
Simpson, B. 2009. Pragmatism, Mead and the Practice Turn. Organization Studies, 30(12): 13291347.

Siti-Nahiba, A. K., \& Scapens, R. W. 2005. Stability and Change: An Institutionalist Study of Management Accounting Change. Accounting, Auditing \& Accountability Journal, 18: 4473.

Smets, M., Morris, T., \& Greenwood, R. 2011. Practice-Driven Institutional Change in Response to Institutional Complexity. Working Paper University of Alberta.

Spee, A. P., \& Jarzbkowski, P. 2009. Strategy tools as Boundary Objects. Strategic Organization, 7(2): 223-232.

Star, S. L., \& Griesemer, J. R. 1989. Institutional Ecology, 'Translations' and Boundary Obects: Amateurs and Professionals in Berkeley's Museum of Vertebrate Zoology, 1907-39. Social Studies of Science, 19(3): 387-420.

Thornton, P. H., \& Ocasio, W. 1999. Institutional Logics and the Historical Contingency of Power in Organizations: Executive Succession in the Higher Education Publishing Industry, 1958-1990. American Journal of Sociology, 105(3): 801-843.

Thornton, P. H., \& Ocasio, W. 2008. Institutional Logics. In R. Greenwood, C. Oliver, S. K. Andersen, \& R. Suddaby (Eds.), Handbook of Organizational Institutionalism. London: Sage.

Thornton, P. H., Ocasio, W., \& Lounsbury, M. forthcoming. Institutional Logics: Theory, Methods and Research. Oxford, UK: Oxford University Press.

Tolbert, P. S., \& Zucker, L. G. 1996. The Institutionalization of Institutional Theory. In S. R. Clegg, C. Hardy, \& W. R. Nord (Eds.), Handbook of Organization Studies: 174-190. London: Sage Publications.

Weick, K. E. 1995. Sensemaking in Organizations. California: Sage.

Weick, K. E., Sutcliffe, K. M., \& Obstfeld, D. 2005. Organizing and the Process of Sensemaking. Organization Science, 16(4): 409-421.

Zilber, T. B. 2002. Institutionalization as an Interplay Between Actions, Meanings, and Actors: The Case of a Rape Crisis Center in Israel. Academy of Management Journal, 45(1): 234-254.

Zucker, L. G. 1988. Where Do Institutional Patterns Come From? Organisations as Actors in Social Systems. In L. G. Zucker (Ed.), Institutional patterns and organizations; Culture and Environment: 23-49. Cambridge: MA: Ballinger.

Zucker, L. G. 1991. Postscript: Microfoundations of Institutional Thought. In W. W. Powell, \& P. J. DiMaggio (Eds.), The New Institutionalism in Organizational Analysis: 103-106. Chicago: University of Chicago Press. 
APPENDIX 1 - COMPANY FACSHEET

\begin{tabular}{|c|c|c|c|c|c|c|c|c|c|}
\hline \multicolumn{2}{|c|}{$\overline{\text { Value }}$} & \multicolumn{3}{|c|}{ Sector } & \multicolumn{2}{|c|}{ Country } & \multicolumn{2}{|r|}{ SRI Analyst } & Date \\
\hline \multicolumn{2}{|c|}{$\mathrm{X}$} & \multicolumn{3}{|c|}{ Banks } & \multicolumn{2}{|c|}{ FRANCE } & \multicolumn{2}{|c|}{ John Smith } & $2008 / 26 / 02$ \\
\hline \multicolumn{5}{|c|}{ Financial Rating } & \multicolumn{5}{|c|}{ SRI Rating } \\
\hline \multicolumn{5}{|c|}{ Exploitation Ratios } & \multicolumn{5}{|c|}{ Quantitative Analysis } \\
\hline Turn Over & $\mathbf{x x x}$ & $\mathbf{x x x x}$ & $\mathbf{x x x}$ & $\mathbf{x x x}$ & Domains & & ting & Innovation $(+)$ & Shortcoming (-) \\
\hline 11740 & 43,71 & 11,12 & 8,03 & 0,43 & Environnement & $\mathrm{xxx}$ & $\begin{array}{l}\text { Excellent } \\
{[. . .]}\end{array}$ & $\begin{array}{l}\text { Co2 emissions are } \\
\text { particurlarly }[\ldots]\end{array}$ & None \\
\hline \multicolumn{5}{|c|}{ Structure Ratios } & Social & $\mathrm{xxx}$ & $\begin{array}{l}\text { Very good } \\
{[\ldots]}\end{array}$ & $\begin{array}{l}\text { Integration of disabled } \\
{[\ldots]}\end{array}$ & $\begin{array}{l}\text { The management of } \\
\text { stress constitutes }[\ldots]\end{array}$ \\
\hline Debt & $\mathbf{x x x}$ & & & & Governance & $\mathrm{xxx}$ & \begin{tabular}{|l|} 
Sector \\
average $[\ldots]$
\end{tabular} & $\begin{array}{l}\text { Good level of } \\
\text { transparence }[\ldots]\end{array}$ & Lack of women $[\ldots]$ \\
\hline 23,78 & & & & & Societal & $\mathrm{xxx}$ & $\begin{array}{l}\text { Weaken } \\
\text { aspect }[\ldots]\end{array}$ & $\begin{array}{l}\text { Discussion on the } \\
\text { elements }[\ldots]\end{array}$ & $\begin{array}{l}\text { A clear lack of } \\
\text { stakeholders }[\ldots]\end{array}$ \\
\hline \multicolumn{5}{|c|}{ Increase Valuation } & \multirow{2}{*}{\multicolumn{5}{|c|}{$\begin{array}{l}\text { CSR Management Systems } \\
>\text { High-level quality of the environmental \& social reporting }\end{array}$}} \\
\hline $\mathbf{x x x}$ & PER & $\mathbf{x x x}$ & $\mathbf{x x x}$ & $\mathbf{x x x}$ & & & & & \\
\hline $1,427 E+10$ & 6,565 & 7,363 & & 0,57 & \multicolumn{5}{|c|}{ Qualitative Analyst } \\
\hline $\begin{array}{c}\begin{array}{c}\text { Price to } \\
\text { book }\end{array} \\
\end{array}$ & Stock & $\mathbf{x x x}$ & $\mathbf{x x x}$ & $\mathbf{x x x}$ & Homogeneity & $\mathrm{xxx}$ & Good & $\begin{array}{l}\text { Risk management is } \\
\text { particurlaly }[\ldots]\end{array}$ & $\begin{array}{l}\text { Societal aspects suffer } \\
\text { from }[\ldots]\end{array}$ \\
\hline 0,82 & 11,68 & 22,24 & 10,25 & $-46,837$ & Dynamism & $\mathrm{xxx}$ & Good & A very good $[\ldots]$ & None \\
\hline \multicolumn{5}{|c|}{ Consensus } & Strategy & $\mathrm{xxx}$ & Good & A good integration in $[\ldots]$ & $\begin{array}{l}\text { A macro analysis would } \\
\text { have been }[\ldots]\end{array}$ \\
\hline Consensus & $\mathbf{x x x}$ & $\overline{x x x}$ & $\mathbf{x x x}$ & $\overline{\mathbf{x x x}}$ & \multicolumn{5}{|c|}{ SRI Analyst Position } \\
\hline 2,684 & 19 & 3 & 11 & 5 & \multirow{2}{*}{\multicolumn{5}{|c|}{ X presents a good profile in terms of [...] but suffers from [...]. }} \\
\hline \multicolumn{5}{|c|}{ Asset Manager Position } & & & & & \\
\hline $\mathrm{X}$ is the bank & $\mathrm{k}$ the more & osed to th & risis...[...] & & \multicolumn{5}{|l|}{ Decision Matrix } \\
\hline
\end{tabular}

